\title{
A case report of rare presentation of granulosa cell tumor with torsion and capsule rupture
}

\author{
Nikhitha Basavaraj*, R. Sasikala, Jessy Varghese
}

Department of Obstetrics and Gynecology, Aarupadai Veedu Medical College, Pondicherry, India

Received: 17 December 2021

Revised: 12 January 2022

Accepted: 13 January 2022

\section{*Correspondence:}

Dr. Nikhitha Basavaraj,

E-mail: nikugowda@gmail.com

Copyright: ( ) the author(s), publisher and licensee Medip Academy. This is an open-access article distributed under the terms of the Creative Commons Attribution Non-Commercial License, which permits unrestricted non-commercial use, distribution, and reproduction in any medium, provided the original work is properly cited.

\section{ABSTRACT}

We report a rare case of granulosa cell tumor (GCT) which has undergone torsion and capsule rupture presenting as acute abdomen. The incidence of ovarian torsion among women of reproductive age is 9.9 per 100,000 where dermoid cyst is more common to undergo torsion.

Keywords: Granulosa cell tumor, Torsion, Rupture, Sex cord stromal tumor

\section{INTRODUCTION}

Sex cord stromal tumor of the ovary account for 5-8\% of all ovarian malignancies. ${ }^{1}$ They are endocrinologically active tumors of which granulosa cell tumor (GCT) is the commonest. GCT secretes oestrogen and are seen in women of all age groups. They are found in pre pubertal girls in $5 \%$ of the cases, the remainder are found in women throughout their reproductive and post-menopausal years. ${ }^{2}$ Abdominal pain and hemoperitoneum, which occasionally can occur, are attributable to torsion and capsule rupture of ovary. We report a rare case of GCT which has undergone torsion and capsule rupture presenting as acute abdomen. ${ }^{5}$

\section{CASE REPORT}

Date of admission was reported to be 19 March 2021.

Date of surgery was 19 March 2021.

Date of discharge was 31 March 2021.

A 40 year old patient hailing from Cuddlore, multiparous, P3L3 came to casualty at 3 am on 19 March 2021 with severe abdominal pain. On examination her pulse was 110 bpm and blood pressure of 90/60 $\mathrm{mm}$ of $\mathrm{Hg}$. On eliciting history patient had similar complaints 1 month back and heavy menstrual bleeding for 4 months, she went to outpatient department (OPD) at private medical college and was advised admission - patient was not willing. Per abdominal examination: abdomen was tender, a mass size of about 24 weeks of gestation was palpable, cystic in consistency, mobile from side to side, tender. No gross free fluid in abdomen. On bimanual examination uterus was found to be enlarged to 10-12 week size, mass was palpable through anterior and left fornix, other fornices were free. Basic investigations done: $\mathrm{Hb}-12.1 \mathrm{gm} / \mathrm{dl}$. Sonography examination revealed Left adnexal large multiloculated cystic lesion (volume: $975 \mathrm{cc}$ ) - seen entirely occupying upto the left lower lumbar region. The lesion shows no internal vascularity within torsion.

\section{Tumor markers}

Tumor markers included: CEA - $0.87 \mathrm{ng} / \mathrm{dl}$ (normal: 0-2.5 $\mathrm{ng} / \mathrm{dl}$ ); CA-125 - 20.17 U/ml (normal :<35 U/ml); Ca19.9 - $20.4 \mathrm{U} / \mathrm{ml}$ (normal: 0-37 U/ml); and inhibin B - 105 $\mathrm{pg} / \mathrm{ml}$ (normal: 0-80 pg/ml). 
Decision of emergency laparotomy was taken immediately in view of diagnosis of torsion of left ovarian cyst. Intra operative findings revealed $100 \mathrm{cc}$ of blood stained fluid in the peritoneal cavity. A large mass of $15 \times 10 \mathrm{~cm}$ arising from the left ovary with rupture of capsule was noted. Uterus enlarged to 10-12 week size with tubes normal. Right ovary was found to be enlarged and congested. Peritoneal fluid was sent for cytology. Total abdominal hysterectomy and bilateral salphingo oophorectomy was done with omental biopsy and specimen was sent for histopathological examination (HPE).

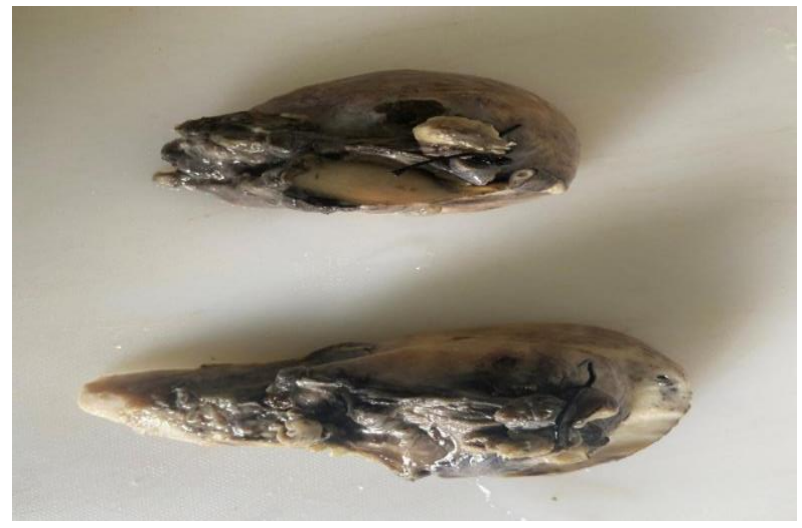

Figure 1: Uterus enlarged to 10-12 week size.

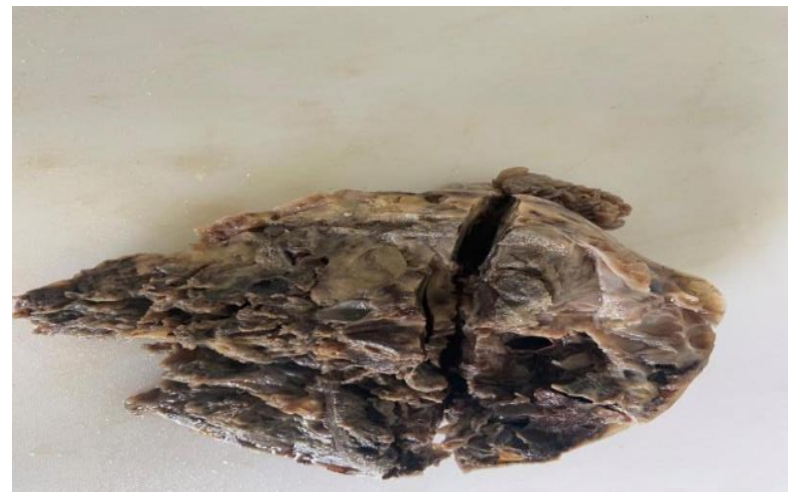

Figure 2: Specimen of ovary with solid and cystic areas.

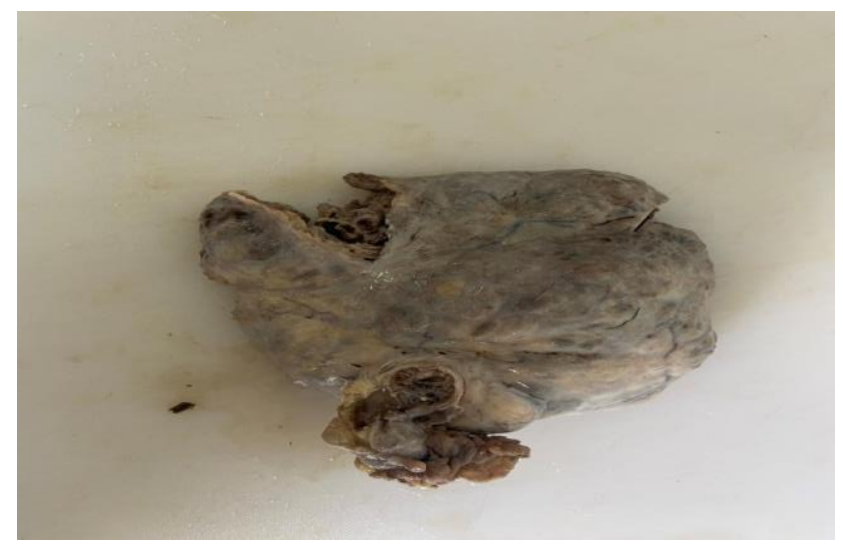

Figure 3: Gross specimen of ovary showing capsular rupture.
HPE report showed (reported on 31 March 2021): capsule ruptured, histology shows GCT, and ascites shows malignant cells.

Cervix shows chronic cervicitis with squamous metaplasia, and nabothian cyst; endometrium shows proliferative phase; fibroid shows adenofibroma; AJCC ( $8^{\mathrm{TH}}$ edition): PT1C3; and FIGO (2018): 1C3.

Post-operative period was uneventful.

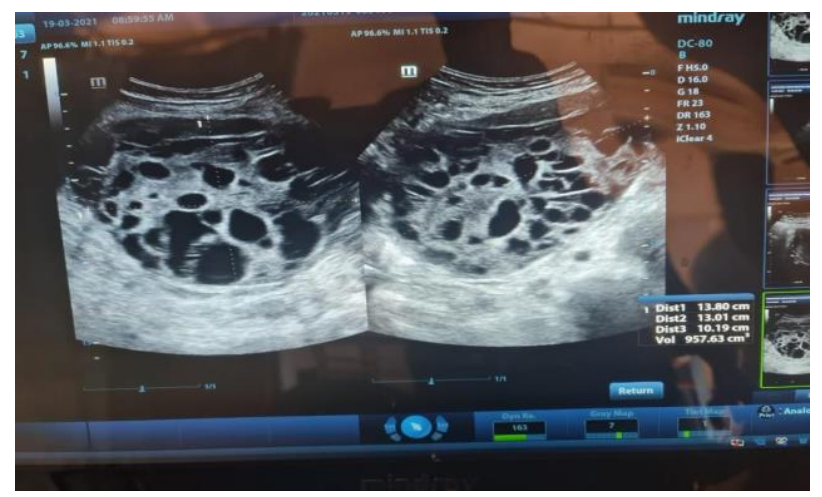

Figure 4: USG abdomen and pelvis showing: left adnexal large multiloculated cystic lesion (volume: 975cc)-seen entirely occupying upto the left lower lumbar region.

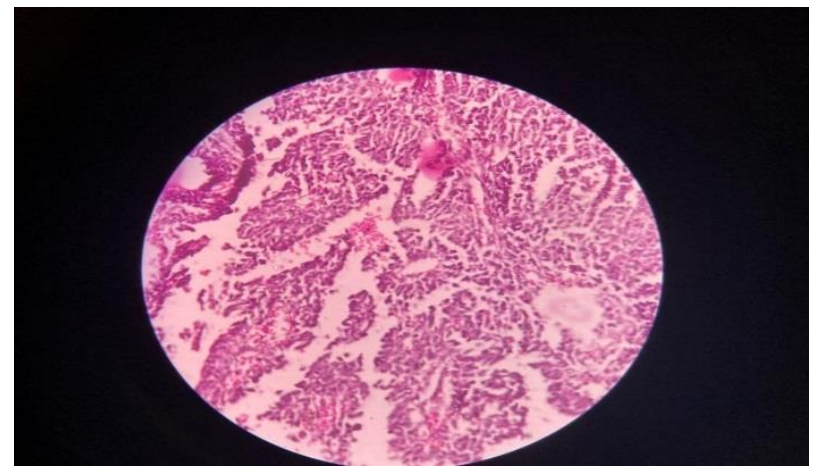

Figure 5: Call Exner bodies seen in granulosa cell tumor.

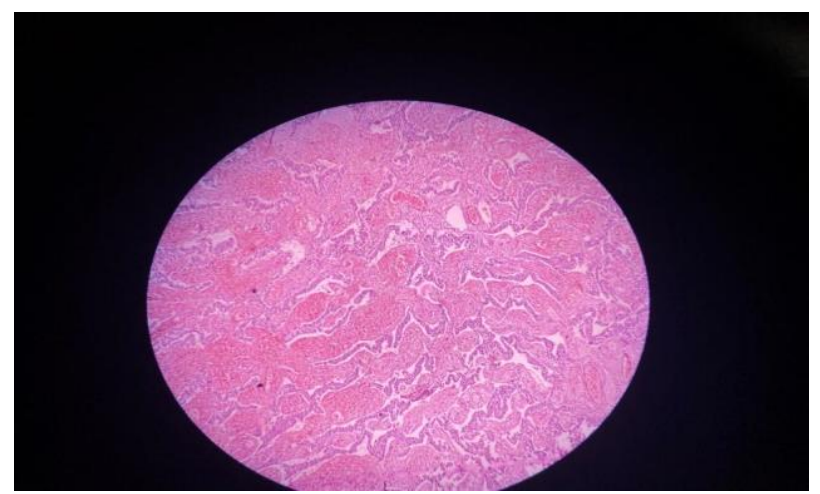

Figure 6: Malignant cells of granulosa cell tumor on microscopy. 


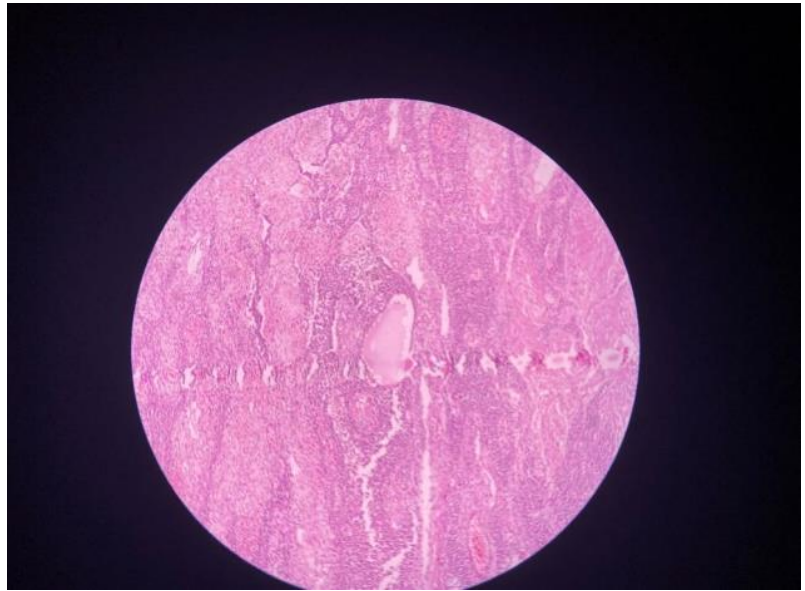

Figure 7: Cystic spaces seen in granulosa cell tumor.

\section{DISCUSSION}

GCTs account for approximately $1 \%$ to $2 \%$ of all ovarian tumors and $70 \%$ of all sex cord stromal tumor. ${ }^{3}$ It has a reported incidence of 0.5-1.5 per 100,000 women per year. ${ }^{3}$ It is mostly seen in peri-menopausal age group with a peak incidence between 50 and 55 years of age. ${ }^{4}$ Bilateral disease is observed in only $2 \%$ of patients. ${ }^{4}$ It is hormonally active tumor producing estrogen. It is divided into adult type and juvenile type depending on the clinicopathological findings, adult type being $95 \%$ of cases. It can manifest as an asymptomatic mass or symptoms related to hyperestrogenism like precocious puberty in adoloscents, abnormal uterine bleeding in reproductive age group and postmenopausal bleeding in post-menopausal age group. ${ }^{6}$ GCT presenting as ovarian torsion is not common. Though there are few reports in juvenile type of tumor, it is very rarely seen in adult type. Tumor rupture is seen in $10 \%$ cases which manifest as abdominal pain and hemoperitoneum. ${ }^{7}$

Imaging findings in adult GCT vary widely and range from solid masses to tumors with varying degree of hemorrhagic or fibrotic changes, to multilocular cystic lesions to completely cystic tumors. Tumor markers used in GCT are estradiol, inhibin, follicle regulatory protein and mullerian inhibitory substance. On gross appearance, it is a pale yellowish large unilateral cyst ranging from a few $\mathrm{mm}$ in size to $30 \mathrm{~cm}$. Two characteristic features of granulosa cell on histopathology are grooved nuclei and Call exner bodies. ${ }^{9}$ Surgery is the primary choice of treatment which alone provides cure in cases with disease confined to the ovaries. However, platinum-based combined chemotherapy regimen is advised in cases with high-risk factor or more advanced disease. ${ }^{8}$

Five year survival rates usually are $90-95 \%$ for stage I tumors compared to $25-50 \%$ for patients presenting with advanced-stage disease. Staging is the most important prognostic factor though other factors like large size $(>15$ $\mathrm{cm})$, bilaterality and tumour rupture can impact greatly on the survival. Despite the good overall prognosis, long term follow-up always is required in patients with GCTs. ${ }^{10} \mathrm{GCT}$ is notorious for its late recurrence, the longest interval reported so far is 40 years. ${ }^{11}$

\section{CONCLUSION}

GCT is a rare ovarian tumor. Torsion and capsule rupture is an addition to its rarity and may present as gynaecological emergency such as acute abdomen. Early diagnosis help in favourable prognosis where surgery is the first line of treatment. Radiation and chemotherapy is used for recurrent and metastatic tumors.

Funding: No funding sources Conflict of interest: None declared Ethical approval: Not required

\section{REFERENCES}

1. Lee IH, Choi CH, Hong DG, Song JY, Kim YJ, Kim KT, et al. Clinicopathologic characteristics of granulosa cell tumors of the ovary: a multicenter retrospective study. J Gynecol Oncol. 2011;22(3):188-95.

2. Kottarathil VD, Antony MA, Nair IR, Pavithran K. Recent advances in granulosa cell tumor ovary: a review. Indian J Surg Oncol. 2013;4(1):37-47.

3. Young RH. Sex Cord-Stromal, Steroid Cell, and Other Ovarian Tumors with Endocrine, Paraendocrine, and Paraneoplastic Manifestations. In: Kurman RJ, Ellenson LH, Ronnett BM, eds. Blaustein's Pathology of the Female Genital Tract. Boston: Springer Publishers. 2011;785-846.

4. Young RH, Dickersin GR, Scully RE. Juvenile granulosa cell tumor of the ovary: a clinicopathological analysis of 125 cases. Am J Surg Pathol. 1984;8(8):575-96.

5. Zaloudek C. The ovary. Gompel C, Silverberg SG, editors. Pathology in Gynecology and Obstetrics. 4th ed. Philadelphia, PA: Lippincott. 1994;313.

6. Ayhan A, Salman MC, Velipasaoglu M, Sakinci M, Yuce K. Prognostic factors in adult granulosa cell tumors of the ovary: a retrospective analysis of 80 cases. J Gynecol Oncol. 2009;20(3):158-63.

7. Hastings RS, Powers RD. Abdominal pain in the ED: a 35 year retrospective. Am J Emerg Med. 2011;29(7):711-6.

8. Chada-Ajwani S. Ovarian Granulosa cell tumors. Histopathology, immunopathology and prognosis. Druk: Krips Repro Meppel. 1987;11-32.

9. Young RH, Dickersin GR, Scully RE. Juvenile granulosa cell tumor of the ovary. A clinic pathological analysis of 125 cases. Beth Israel Deaconess Medical Center, Boston. Am J Surg Pathol. 1984;8(8):575-96..

10. Program in Gynecologic Medical Oncology, Beth Israel Deaconess Medical Center, Boston. Available at: https://www.bidmc.org/centers-and-departments/ cancer-center/cancer-center-programs-and-services/ 
gynecologic-oncology-program. Accessed on 12 October 2021.

11. Magowan BA. Gynaecology. 3rd edition. Churchill Livingstone. 2005.
Cite this article as: Basavaraj N, Sasikala R, Varghese J. A case report of rare presentation of granulosa cell tumor with torsion and capsule rupture. Int J Reprod Contracept Obstet Gynecol 2022;11:628-31. 